\title{
Neuropsychologist's death sparks enquiries
}

\begin{abstract}
Montreal. McGill University in Montreal has set up three separate enquiries into the circumstances surrounding the suicide of a prominent neuropsychologist. Her death followed the revelation that she had been given a reprimand - which she was continuing to contest - for failing to observe the university's regulations on the use of human subjects in experiments.
\end{abstract}

Justine Sergent, an associate professor in the Montreal Neurological Institute, an affiliate of the university, was found dead last month together with her husband, Yves Sergent, after the publication of an article referring to her reprimand appeared in The Montreal Gazette.

In a letter sent shortly before her death to a number of faculty members at McGill, Sergent had claimed that she had been locked in a continuing struggle with other members of her institute over a number of years, and that the referral of her activities to the ethics committee's had been motivated by professional jealousy. But the latter charge has been strongly rejected by university officials. In a memorandum to staff and students, Richard Murphy, the head of the institute, says that allegations that the committee acted for other than ethical reasons were "completely untrue".

"In dealing with an extremely difficult situation, our ethics committee was meticulous," wrote Murphy. "Its decisions were based on the facts, and it has followed its mandate to protect the interests of the volunteers that participate in our research."

Sergent had been working on the origins of the functional lateralization of the brain, using positron emission tomography (PET) to record patterns of activity within the brains of human subjects. She had published in a number of prominent journals, including both Science and Nature.

Some of her results had been contested by other members of the institute. In 1992, for example, she and two colleagues published a report in Science indicating, among other results, that she had not been able to find a response to musical melodies in a particular region of the brain.

A paper published last month by other members of the institute reports such a response, and suggested that Sergent's failure to observe a response had resulted from inappropriate control conditions (Journal of Neuroscience, 14(4), 1908-1919; 1994).

Her reprimand by the university followed her use of PET techniques for testing subjects' reactions to stimuli provided by musical notation. Sergent had received the approval of the ethics committee for experiments using human faces as visual stimuli. But she went on to use the same technique for testing reactions to musical notation, and believed the ethics committee's approval covered that experiment as well.

Sergent argued in her defence that her subjects gave fully informed consent to being tested, and that their health was not compromised in any way, with which McGill concurs. But, following an inquiry by the ethics committee, she was reprimanded by the principal of the university in January 1993 for what the university has described

\section{Clementine's 'not gone forever'}

The Clementine spacecraft - which captured this image of the Earth on its Moon visit last month - had already proved itself before an engine misfiring sent it into a 70 r.p.m. spin, its supporters say.

c. $\mathbf{M}$.

The craft - a low-cost offshoot of the Department of Defense's nowdefunct Star Wars programme (Nature 367, 207; 1994) — had its mishap ten days ago. Coming immediately after a blaze of publicity which favourably compared the $\$ 80$ million mission to more expensive space projects, this no doubt brought quiet satisfaction to some dull lives at NASA headquarters.

But Stewart Nozette, deputy manager of the Clementine programme, says its primary goals are already being met and that the technology has proved itself. After weekend tests,

he reports that the craft will "definitely get to a stable situation." Mission control hopes to slow the spin to 20 r.p.m. and then decide whether to send Clementine on to the asteroid Geographos, as originally planned.

\section{IMAGE UNAVAILABLE FOR COPYRIGHT REASONS}

as "academic misconduct".

The reprimand became public as the result of an anonymous letter sent to the Gazette - as well as to senior officials in the university, the Medical Research Council and another funding agency - which claimed she had built her scientific career on the basis of what colleagues at McGill had long suspected was scientific fraud. (None of her collaborators was implicated in any way.)

The Gazette learned about the reprimand from a statement sent to the newspaper by the university in response to the letter and its allegations. Its subsequent article was published after an interview with university representatives and with Sergent in which the newspaper's editor later said both had described their positions "coherently and without rancour".

In a subsequent letter published by the newspaper, a group of Montreal neuropsychologists and other scientists expressed concern that it had published allegations of scientific fraud "without waiting for the results of an official investigation". They described Sergent as "among the most productive neuropsychologists in Canada".

In a separate article, Peter T. Fox, director of the research-imaging centre at the University of Texas Health Science Center in San Antonio, Texas, claimed that Sergent had been a casualty of both her own "uncompromising standards of excellence" and of an "inhospitable work environment".

He described allegations that Sergent, who had been a close personal friend as well as a scientific colleague, might have committed a scientific fraud as "a deliberate and outrageous falsehood". He also claimed that Sergent found herself under pressure as a woman in a field that remains male-dominated, and described her $\mathrm{PhD}$ degree in psychology as an anomaly in a medical department which "could only have made her situation less certain and more stressful".

The university has rejected Fox's implication that the judgement of the ethics committee was based on issues other than ethical concerns. But, in response to a request from Sergent - who had hired a lawyer to defend herself against the university's charges the university is carrying out a scientific audit of her work.

This is being conducted by Pierre Bois, a past president of the Medical Research Council, and Marcus Raichle of Washington University in St Louis, Missouri, a respected authority on PET.

A separate inquiry will be conducted by Caspar Bloom, president of the Montreal bar, into McGill's internal procedures and the way that these were applied to Sergent's case. The university is also trying to find out who sent the original allegations of scientific misconduct to the newspaper.

David Spurgeon 